\title{
Physiological potential of Dyckia spp. bromeliad seeds under different temperatures
}

\section{Potencial fisiológico de sementes de bromélias Dyckia sp. sob diferentes temperaturas}

\author{
Verônica Pellizzaro Moresco ${ }^{1 *}$; Mônica Satie Omura ${ }^{1}$; Jean Carlo Baudraz de \\ Paula'; Felipe Favoretto Furlan'; Lúcia Sadayo Assari Takahashi²
}

\section{Highlights}

Bromeliads of the genus Dyckia have potential in the ornamental plant market. Ideal temperatures for carrying out tests guarantee their success.

The results of this study will contribute to future work.

The number of days to carry out germination and vigor tests was established.

The best temperature to assess the physiological potential was identified.

\begin{abstract}
Bromeliads have been gaining ground in the economic scenario due mainly to their use as ornamental plants. Bromeliads of the genus Dyckia exhibit different morphologies, and therefore, have relevance in this market. However, some species are threatened due to the extraction of plants from their natural environments. Many of these species are endemic and native to Brazil and there are few studies on their seed physiology; hence, expansion of research into this topic is essential. An alternative for the preservation of such plants is the production of seedlings using seeds. To this end, the objective of this work was to evaluate the physiological potential of seeds of Dyckia brevifolia, Dyckia beateae, and Dyckia excelsa at different temperatures, and determine the number of days to carry out the tests. A completely randomized design was adopted, with three species of Dyckia, analyzed separately, and four temperatures $\left(20,25,30\right.$, and $\left.35^{\circ} \mathrm{C}\right)$. The following were evaluated: first germination count, germination, germination speed index, length of seedling, and seedling dry weight. The data were analyzed using the Sisvar software for normality and homogeneity, and when the assumptions were met, they were subjected to analysis of variance using the F test $(p<0.05)$ and the means were compared using the Tukey test at $5 \%$ probability. Seeds of $D$. excelsa emit the radicle more quickly at 20 and $35^{\circ} \mathrm{C}$; however, temperatures of 25 and $30{ }^{\circ} \mathrm{C}$ provide better conditions for seedling growth and development. The greatest vigor of $D$. brevifolia seeds is
\end{abstract}

1 Drs. in Agronomy, Universidade Estadual de Londrina, UEL, Center of Agrarian Sciences, Londrina, PR, Brazil. E-mail: veronicapellizzaro@hotmail.com; monica_omura@hotmail.com; jc_baudraz@live.com; ffavorettofurlan@gmail. com;

2 Profa Dra, Senior, Department of Agronomy, Graduate Program in Agronomy, UEL, Londrina, PR, Brazil. E-mail: sadayo@uel.br

* Author for correspondence

Received: Aug. 05, 2020 - Approved: May 31, 2021 
observed at temperatures of 30 and $35^{\circ} \mathrm{C}$. Seeds of $D$. beateae emit the radicle more quickly at $20^{\circ} \mathrm{C}$, and the largest seedlings are observed at $35^{\circ} \mathrm{C}$. The first germination count of $D$. brevifolia, $D$. beateae, and $D$. excelsa should be evaluated on the third day after sowing. The germination evaluations for $D$. excelsa and $D$. beateae should be carried out on the ninth day after sowing, and those for $D$. brevifolia on the sixth day after sowing.

Key words: Bromeliaceae. Dyckia beateae. Dyckia brevifolia. Dyckia excelsa. Germination. Vigor.

\section{Resumo}

As bromélias vêm ganhando espaço no cenário econômico em função principalmente do uso como plantas ornamentais. Bromélias do gênero Dyckia sp., apresentam morfologia diferenciada e, por isso, possuem relevância neste mercado, no entanto, algumas espécies estão ameaçadas devido ao extrativismo das plantas de seus ambientes naturais. Muitas destas espécies são endêmicas e nativas do Brasil e são poucos os estudos sobre a fisiologia de sementes destas plantas, sendo essencial o desenvolvimento de pesquisas. Uma alternativa para preservação é a produção de mudas via sementes. Neste sentido, o objetivo do trabalho foi avaliar o potencial fisiológico de sementes de $D$. brevifolia, $D$. beateae e $D$. excelsa em diferentes temperaturas e estabelecer o número de dias para a realização dos testes. Adotou-se delineamento inteiramente casualizado, contendo três espécies de Dyckia ( $D$. brevifolia, $D$. beateae e $D$. excelsa), analisadas separadamente, e quatro temperaturas $\left(20^{\circ} \mathrm{C}, 25^{\circ} \mathrm{C}, 30^{\circ} \mathrm{C}\right.$ e $\left.35^{\circ} \mathrm{C}\right)$. Foram avaliadas: primeira contagem de germinação, germinação, índice de velocidade de germinação, comprimento e massa seca de plântulas. Os dados foram analisados pelo software Sisvar quanto à normalidade e homogeneidade e ao atenderem os pressupostos foram submetidos à análise de variância pelo teste F $(p<0,05)$ e as médias comparadas pelo teste de Tukey a $5 \%$ de probabilidade. Sementes de Dyckia excelsa emitem a radícula mais rapidamente a $20^{\circ} \mathrm{C}$ e $35^{\circ} \mathrm{C}$; no entanto as temperaturas de $25^{\circ} \mathrm{C}$ e $30^{\circ} \mathrm{C}$ proporcionam melhores condições para o crescimento e desenvolvimento das plântulas. O maior vigor de sementes de Dyckia brevifolia é observado nas temperaturas de $30^{\circ} \mathrm{C}$ e $35^{\circ} \mathrm{C}$. As sementes da espécie Dyckia beateae emitem a radícula mais rapidamente a $20^{\circ} \mathrm{C}$ e as maiores plântulas são observadas a $35^{\circ} \mathrm{C}$. A primeira contagem de germinação de $D$. brevifolia, $D$. beateae e $D$. excelsa deve ser avaliada no terceiro dia após a semeadura e as avaliações de germinação para $D$. excelsa e $D$. beateae devem ser realizadas ao nono dia após a semeadura, para $D$. brevifolia ao sexto dia após a semeadura.

Palavras-chave: Bromeliaceae. Dyckia beateae. Dyckia brevifolia. Dyckia excelsa. Germinação. Vigor.

\section{Introduction}

Bromeliads belong to the Bromeliaceae family, which comprises 52 genera and 3,320 species, and is one of the largest families of angiosperms, with a predominant presence in the American continent (Givnish et al., 2011; The Plant List, 2020). In addition, Brazil is a great center of diversity for species of the genus Dyckia, housing more than $80 \%$ of the species of this genus, with 129 species registered, of which 120 are endemic and distributed in the biomes of the Atlantic Forest, Restinga, Caatinga, Campos Rupestres, and Cerrado (Leme, Ribeiro, \& Miranda, 2012; Reflora, 2020).

The genus Dyckia comprises plants that do not have the water "reservoir" commonly seen in other genera. They are terrestrial rupicolous plants that develop in 
well-drained soils or rocky outcrops, and arid environments such as deserts; some species, the so-called rheophytes, manage to survive in flooded environments (Leme et al., 2012).

The use of bromeliads as ornamental plants in Brazil began in the 1970s, and has become widely accepted by consumers, justified by the beauty of the colorful leaves and the durability of the flowers (Anacleto \& Negrelle, 2009). However, owing to the great demand for bromeliads, some species, including those of the genus Dyckia, are threatened due to their extraction from their natural environments, contributing to an increase in the number of vulnerable, damaged, or even endangered plants (Bered, Santos, Palma, \& Paggi, 2008). An alternative for the preservation of these threatened species is the production of seedlings using seeds, which has advantages of genetic diversity preservation, reduced cost, and low environmental impact (Silva, Souza, Resente, \& Gonçalves, 2018).

The species Dyckia brevifolia Baker is a rheophyte and is restricted to the rocky banks of the Itajaí-Açu River in Santa Catarina, forming clumps and characterized by triangular leaves of light green color. Dyckia beateae E. Gross \& Rauh is a heliophyte species, whether terrestrial or rupicolous, and is found in the Cerrado, mainly in the state of Mato Grosso. Dyckia excelsa Ducke is rupicolous and grows in rocky outcrops in western Mato Grosso do Sul. All these species are native and endemic to Brazil (Reflora, 2020).

However, knowledge about the physiology of bromeliad seeds is scarce, since there are no recommendations for the species under study in the Seed Analysis Rules (Ministério da Agricultura, Pecuária e
Abastecimento [MAPA], 2009). The quality of the seeds can be determined using several tests, such as the germination test; however, other tests of vigor are necessary as they allow the identification of lots with better performance in the field or during storage, and are important instruments as adjuncts to the germination test in seed quality research (Guedes, Alves, Gonçalves, Santos, \& Lima, 2009).

The first count of germination test can be used as a vigor test, since the germination speed reduces upon deterioration of the seed. Seeds that produce seedlings with larger values of length of the aerial part and green or dry weight are considered more vigorous; these parameters can also be used as a vigor test. For this, establishing criteria and standards for carrying out these tests are fundamental to characterize the physiological potential of the seeds (Guedes et al., 2009).

Temperature plays a fundamental role in the physiological potential of the seeds, acting directly on the germination; modifying its intensity and speed; regulating the rates of imbibition, release of electrolytes, and mobilization of reserves; and affecting the growth and vigor of the seedlings. Thus, temperature acts directly on biochemical reactions, influencing germination uniformity, which directly affects seed vigor (Pacheco, Silva, Negreiros, Silva, \& Farias, 2013; Ataíde et al., 2013).

Therefore, there is a need for research to determine the ideal temperature for carrying out twinning and vigor tests, since it is a factor that affects the metabolism for the initial development, establishment, and survival of seedlings at the place of cultivation (Marcos, 2015). The appropriate temperature 
for the germination and vigor tests of Dyckia spp. does not always coincide with that for other genera. Wiesbauer, Scariot, Sasaki and Reis (2007) observed that seeds of Dyckia distachya Hassler exhibited maximum germination in the presence of light and at room temperature, ranging from 21 to $30^{\circ} \mathrm{C}$. On the other hand, seeds of Dyckia tuberosa showed greater germination capacity and uniformity when subjected to temperatures between 30 and $35{ }^{\circ} \mathrm{C}$ (Vieira, Socolowski, \& Takaki, 2007).

Studies can explain some biogeographical peculiarities of certain species, such as their geographic distribution and why they inhabit a particular location, since they can germinate in a wide thermal range depending on the biome and region (Kovalenko \& Kalista, 2019).

To this end, the objective of this work was to evaluate the physiological potential of seeds of D. brevifolia, D. beateae, and D. excelsa at different temperatures, and establish the number of days to carry out the tests.

\section{Materials and Methods}

This study was conducted at the Seed Analysis Laboratory of the Center for Agricultural Sciences (CCA) of the State University of Londrina (UEL). Five thousand seeds (1725 mg) of each Dyckia species tested (D. brevifolia, $D$. beateae, and $D$. excelsa) were collected in December 2018 from a natural plant population located in the municipality of Londrina - PR (Latitude: -23.2927; Longitude: $-51.173223^{\circ}$; Altitude: $550 \mathrm{~m}$ ).

After manual extraction, the seeds were stored in a cold chamber $\left(9 \pm 2{ }^{\circ} \mathrm{C}\right)$ until the test (after 60 days). The design was completely randomized, with three Dyckia species, analyzed separately, and four temperatures for the tests $(20,25,30$, and $35^{\circ} \mathrm{C}$ ), all in the presence of light, with four repetitions using 50 seeds per treatment. The following evaluations were carried out: first germination count (FGC), germination (GER), germination speed index (GSI), length of seedling (LS), and seedling dry weight (SDW).

The duration of the GER, FGC, and GSI tests was established based on studies with other species of the genus Dyckia and the performance of pre-tests, in order to observe and determine the beginning and end of germination for the species under study.

The FGC was conducted using the GER test, at the time of the protrusion of the primary root of the first seedling, on the third day after sowing. The results were expressed as percentages of normal seedlings (Nakagawa, 1999).

In the GER test, four replications of 50 seeds were sown on blotting paper (10.5 $\times 10.5$ $\mathrm{cm}$ ) moistened with distilled water, at an amount equivalent to 2.5 times the weight of the dry paper, and placed inside transparent plastic boxes $\left(G^{-}\right.$rbox $\left.^{\circledR}\right)(11.5 \times 11.5 \times 3.5 \mathrm{~cm})$ (MAPA, 2009). After being packed in plastic bags, they were kept in a BOD-type germination chamber regulated at $20,25,30$, or $35^{\circ} \mathrm{C}$ under a $24 \mathrm{~h}$ light regime. The GER evaluation was carried out according to the recommendations of the Rules for Seed Analysis - RAS (MAPA, 2009); the seedlings that showed potential to continue their development and give rise to normal plants were considered normal. The results were obtained on the sixth day after setting up the experiment for $D$. brevifolia and on the ninth day for $D$. excelsa and $D$. beateae, and expressed as percentages. 
The GSI test was performed concurrently with the GER test. The germinated seed count was performed daily throughout the GER test, considering those with a minimum radicle length of $2 \mathrm{~mm}$, following the equation described by Maguire (1962): GSI = $\mathrm{G} 1 / \mathrm{N} 1+\mathrm{G} 2$ / N2 + ... $+\mathrm{Gn} / \mathrm{Nn}$, where G1, G2, and $\mathrm{Gn}$ are the numbers of normal seedlings computed in the first, second, and last counts, respectively; and $\mathrm{N} 1, \mathrm{~N} 2$, and $\mathrm{Nn}$ are the corresponding number of days from sowing to the first, second, and last counts.

At the end of the GER test, the LS was evaluated by measuring ten normal seedlings with the aid of a ruler graduated in centimeters $(\mathrm{cm})$, with the results expressed in cm seedling $^{-1}$ (Nakagawa, 1999).

The SDW was determined after measuring the length; similar seedlings were packed in Kraft paper bags, kept in a forced circulation oven at $80{ }^{\circ} \mathrm{C}$ for $24 \mathrm{~h}$, and then weighed on a precision scale (method adapted from Nakagawa, 1999). The results were expressed in mg seedling $^{-1}$.

The data were analyzed for normality and homogeneity; when they met the assumptions, they were subjected to analysis of variance by the $F$ test $(p<0.05)$, and the means were compared using the Tukey test at $5 \%$ probability.

\section{Results and Discussion}

The seeds emitted radicles on the third day after sowing (DAS). The number of days necessary to carry out the GER test of the species was established; for $D$. brevifolia, it must be performed on the sixth DAS, and for $D$. excelsa and $D$. beateae, on the ninth.

Among the variables analyzed for the physiological potential of seeds of Dyckia spp. at different temperatures, there was a significant difference in the FGC and LS for all the studied species. In addition, there was a significant difference in the GSI for $D$. brevifolia, as well as in the SDW for $D$. beateae and D. brevifolia (Table 1).

The seeds of D. brevifolia showed greater vigor (evaluated using FGC, GSI, LS, and SDW tests) when subjected to temperatures of 30 and $35{ }^{\circ} \mathrm{C}$, obtaining FGCs of $94 \%$ and $98 \%$, respectively (Table 2 ).

Seed vigor is the resumption of the set of metabolic transformations responsible for germination in a sequential and organized manner (Rajjou et al., 2012). It is observed that when there is an increase in temperature, vigor is favored, that is, germination and establishment occur more quickly, reducing the time of exposure to pathogens and pests that inhabit the soil. 
Table 1

Analysis of variance with mean square values for the variables first germination count (FGC), germination (GER), germination speed index (GSI), length of seedling (LS), and seedling dry weight (SDW) of Dyckia excelsa, Dyckia brevifolia, and Dyckia beateae as a function of the physiological behavior of seeds at different temperatures $\left(20,25,30\right.$, and $\left.35^{\circ} \mathrm{C}\right)$

\begin{tabular}{cccccc}
\hline Variation Source & FGC & GER & GSI & LS & SDW \\
Temperature & $901.56^{* *}$ & $5.72^{\text {ns }}$ & $11.45^{*}$ & $0.07^{* *}$ & $0.00^{* *}$ \\
CV & 14.35 & 3.4 & 5.18 & 6.71 & 13.86 \\
Variation Source & FGC & D. beateae & & \\
Temperature & $1551.56^{* *}$ & $529.16^{\text {ns }}$ & $45.24^{\text {ns }}$ & $0.07^{* *}$ & $0.00^{*}$ \\
CV & 37.83 & 15.04 & 20.28 & 7.8 & 26.29 \\
Variation Source & FGC & D. excelsa & & \\
Temperature & $763.02^{* *}$ & GER & GSI & LS & SDW \\
CV & 37.2 & 18.56 & $34.45^{\text {ns }}$ & $0.01^{* *}$ & $0.00^{\text {ns }}$ \\
\end{tabular}

** Significant at $1 \%$; * Significant at $5 \%$; ns: Not significant by the $\mathrm{F}$ test $(\mathrm{p}<0.05)$.

Table 2

Effect of temperature $\left(20,25,30\right.$, and $\left.35^{\circ} \mathrm{C}\right)$ on the physiological potential of bromeliads Dyckia excelsa, Dyckia brevifolia, and Dyckia beateae with respect to the characteristics of first germination count (FGC) (\%), germination speed index (GSI), length of seedling (LS) (cm), and seedling dry weight (SDW) (g)

\begin{tabular}{|c|c|c|c|c|c|}
\hline \multicolumn{6}{|c|}{ D. brevifolia } \\
\hline Temperature & FGC & GER & GSI & LS & SDW \\
\hline $20^{\circ} \mathrm{C}$ & $68 C^{*}$ & 99 & 28.75 B & $0.36 \mathrm{C}$ & $0.0014 \mathrm{C}$ \\
\hline $25^{\circ} \mathrm{C}$ & $73 \mathrm{BC}$ & 96 & $30.20 \mathrm{AB}$ & $0.52 \mathrm{~B}$ & $0.0025 \mathrm{AB}$ \\
\hline $30^{\circ} \mathrm{C}$ & $94 \mathrm{AB}$ & 96 & $31.87 \mathrm{AB}$ & $0.70 \mathrm{~A}$ & $0.0020 \mathrm{BC}$ \\
\hline $35^{\circ} \mathrm{C}$ & $98 \mathrm{~A}$ & 98 & $32.50 \mathrm{~A}$ & $0.46 \mathrm{~B}$ & $0.0028 \mathrm{~A}$ \\
\hline \multicolumn{6}{|c|}{ D. beateae } \\
\hline Temperature & FGC & GER & GSI & LS & SDW \\
\hline $20^{\circ} \mathrm{C}$ & $49 \mathrm{~A}$ & 96 & 22.88 & $0.50 \mathrm{~B}$ & 0.003 \\
\hline $25^{\circ} \mathrm{C}$ & $8 \mathrm{C}$ & 978 & 19.55 & $0.54 \mathrm{~B}$ & 0.005 \\
\hline $30^{\circ} \mathrm{C}$ & $28 \mathrm{~B}$ & 89 & 20.87 & $0.35 \mathrm{C}$ & 0.003 \\
\hline $35^{\circ} \mathrm{C}$ & $8 \mathrm{C}$ & 73 & 14.95 & $0.69 \mathrm{~A}$ & 0.006 \\
\hline \multicolumn{6}{|c|}{ D. excelsa } \\
\hline Temperature & FGC & GER & GSI & LS & SDW \\
\hline $20^{\circ} \mathrm{C}$ & $31 \mathrm{~A}$ & 96 & 19.43 & $0.57 \mathrm{AB}$ & 0.003 \\
\hline $25^{\circ} \mathrm{C}$ & $13 \mathrm{~B}$ & 60 & 13.30 & $0.63 \mathrm{~A}$ & 0.004 \\
\hline $30^{\circ} \mathrm{C}$ & $6 \mathrm{~B}$ & 70 & 16.97 & $0.59 \mathrm{~A}$ & 0.004 \\
\hline $35^{\circ} \mathrm{C}$ & $34 \mathrm{~A}$ & 71 & 19.58 & $0.51 \mathrm{~B}$ & 0.005 \\
\hline
\end{tabular}

* Averages followed by the same letter in the column do not differ by the Tukey test at $5 \%$ significance. 
For all species, there is an optimal temperature range for complete metabolic performance (Dürr, Dickie, Yang, \& Pritchard, 2015); outside this range, inhibition may occur, causing damage to the germination process (Marcos, 2015). According to Gualtieri and Fanti (2015), germination under extreme temperatures leads to thermo-denaturation of proteins and inactivation of enzymes, which affects the lipid bilayer of membranes and promotes changes in the lipid organization of cell membranes, and consequently, causes loss of their function. All these factors lead to reduced seed vigor and germination potential.

In general, species present optimum, maximum, and minimum temperatures for germination. The optimum temperature is that at which a species presents the maximum germination in the shortest time. Any temperature below or above the optimum tends to reduce the speed of the germination process, exposing seedlings for a longer period to adverse factors, which can cause the interruption of germination due to the direct influence of temperature on enzymatic reactions (Valadares \& Paula, 2008; Ferreira, Matos, Sales, \& Pacheco, 2008).

According to the results of the study by Duarte, Carneiro, Silva and Guimarães (2010), carried out with seeds of Dyckia goehringii Gross \& Rauh, the optimal variables that determined the seed physiological potential (GER, GSI, LS, and SDW) were found at $30^{\circ} \mathrm{C}$. These results corroborate the findings of the present study for the species $D$. brevifolia.

Pompelli(2006)studied the germination of Dyckia encholirioides (Gaud) Mez. var. encholirioides and verified an average delay of three days for initiation of germination when the seeds were pre-cooled for $48 \mathrm{~h}$ at $4 \pm 2{ }^{\circ} \mathrm{C}$, and up to nine days when treated for $168 \mathrm{~h}$ at the same temperature, indicating that the low temperature affected the germination time probably by decreasing the metabolic activity and/or causing damage.

Pinheiro and Borghetti (2003), who studied bromeliads of the sandbank Aechmea nudicaulis (L.) Griesebach and Streptocalyx floribundus (Martius ex Schultes F.) Mez., found that the seeds had a better germinative performance between 20 and $30^{\circ} \mathrm{C}$, with $98 \%$ GER; at $15^{\circ} \mathrm{C}$, GER reduced to $85 \%$, and at high temperatures, such as $45{ }^{\circ} \mathrm{C}$, to $38 \%$. These results emphasize that temperature extremes directly influence the enzymatic and metabolic activity of the seeds during germination.

As shown in Table 2, for the species $D$. beateae, the highest FGC (48.75\%) was obtained at the lowest temperature $\left(20{ }^{\circ} \mathrm{C}\right)$, and it decreased to $7.5 \%$ at the highest temperature $\left(35^{\circ} \mathrm{C}\right)$. On the other hand, for the species $D$. excelsa, the highest FGC was found at the extremes of the tested temperatures: $31.25 \%$ at $20{ }^{\circ} \mathrm{C}$ and $33.75 \%$ at $35{ }^{\circ} \mathrm{C}$. The physiology of two species of the same genus mayvary; this explains the greater resistance of D. beateae at low temperatures and $D$. excelsa at great thermal amplitudes. Both grow in the Cerrado, which has large thermal amplitude as a climatic characteristic at certain times of the year, and each species has mechanisms that respond differently to such temperatures.

According to Vieira et al. (2007), seeds of Dyckia tuberosa (Vellozo) Beer showed high GER (75\%) at $15^{\circ} \mathrm{C}$ in the light. However, this indicates heterogeneous behavior of the germination both in the presence and absence of light. This adaptation behavior to different temperatures can be considered valuable for the maintenance of bank seeds in the soil (Souza, Rodrigues, \& Joly, 2017). This strategy enables greater efficiency in the 
establishment of seedlings, as they can find ideal conditions for their development (Vieira et al., 2007).

According to Duarte et al. (2010), for most species of bromeliads, temperatures between 25 and $30{ }^{\circ} \mathrm{C}$ are favorable for the germination process, which takes an average of 7 to 28 days at $25^{\circ} \mathrm{C}$. In addition, in the absence of limiting factors, germination occurs under a wide temperature range (Marcos, 2015). For the species under study, germination took, on average, from 3 to 9 days. As shown in Table 2 , for $D$. brevifolia, the GSI did not differ at temperatures of 20,25 , and $30^{\circ} \mathrm{C}$. However, it was higher at $35^{\circ} \mathrm{C}$, and only differed from that at $20^{\circ} \mathrm{C}$. According to Carvalho and Nakagawa (2000), the germination speed will be higher at higher temperatures, as this factor affects biochemical reactions, which determine the entire germination process.

Duarte et al. (2010), after a study carried out with seeds of D. goehringii Gross \& Rauh, concluded that the best temperature for the germination of the seeds was $30^{\circ} \mathrm{C}$, with germination beginning on the fourth DAS and stabilizing between the eighth and tenth DAS for large seeds.

Germination of $D$. distachya Hassler occurs at the end of the first week of the GER test conducted under environmental conditions and at temperatures between 21 and $30^{\circ} \mathrm{C}$ (Wiesbauer et al., 2007). Vieira et al. (2007) found that in the temperature range of $18-20^{\circ} \mathrm{C}$, seeds of $D$. tuberosa (Vellozo) Beer germinated between 15 and 20 days after sowing, although the optimum germination temperature range for this species is between 20 and $40^{\circ} \mathrm{C}$.

As for the characteristic LS, the highest averages were observed at temperatures of $30{ }^{\circ} \mathrm{C}$ for $D$. brevifolia $(0.70 \mathrm{~cm}), 35^{\circ} \mathrm{C}$ for
$D$. beateae (with an average of $0.69 \mathrm{~cm}$ ), and between 25 and $30^{\circ} \mathrm{C}$ for $D$. excelsa; however, they did not differ from the LS at $20^{\circ} \mathrm{C}$ for the latter species (Table 2). Temperatures below $20{ }^{\circ} \mathrm{C}$ induce a slower metabolism and thus shorter LS. In addition to causing structural and morphological changes in plants, cold stress can prevent the development of seedlings by restricting energy use, and consequently, cause the formation of free radicals, which irreversibly damage the seedlings (Arbona, Manzi, Ollas, \& Gómez-Cadenas, 2013). Low temperatures affect metabolism by altering the cell cycle, membrane fluidity, and sugar accumulation, and cause changes in the cytoskeleton rearrangement and even in the composition of photosynthetic pigments (Benson, 2008).

After a study with $D$. goehringii Gross \& Rauh, Duarte et al. (2010) reported that the highest average of LS was observed at temperatures of 25 and $30{ }^{\circ} \mathrm{C}(1.475 \pm 0.075$ $\mathrm{cm})$, and the lowest average, at $20^{\circ} \mathrm{C}(0.435 \pm$ 0.05).

The species differed in terms of the ideal temperature range for their development, which is probably related to the temperature range present in the region of origin, favoring a better germinative performance when all favorable environmental conditions were offered (Figure 1) (Marcos, 2015). Plants of the genus Dyckia are adapted to extreme temperature conditions. Many, such as $D$. beateae, $D$. excelsa, and $D$. brevifolia, grow in the Cerrado and suffer constantly from periods of floods and droughts, which make these species present mechanisms that allow adaptation under extreme conditions such as the presence of trichomes, spines, and Crassulacean acid metabolism (CAM), and strategies that allow survival in the regions where they occur. 


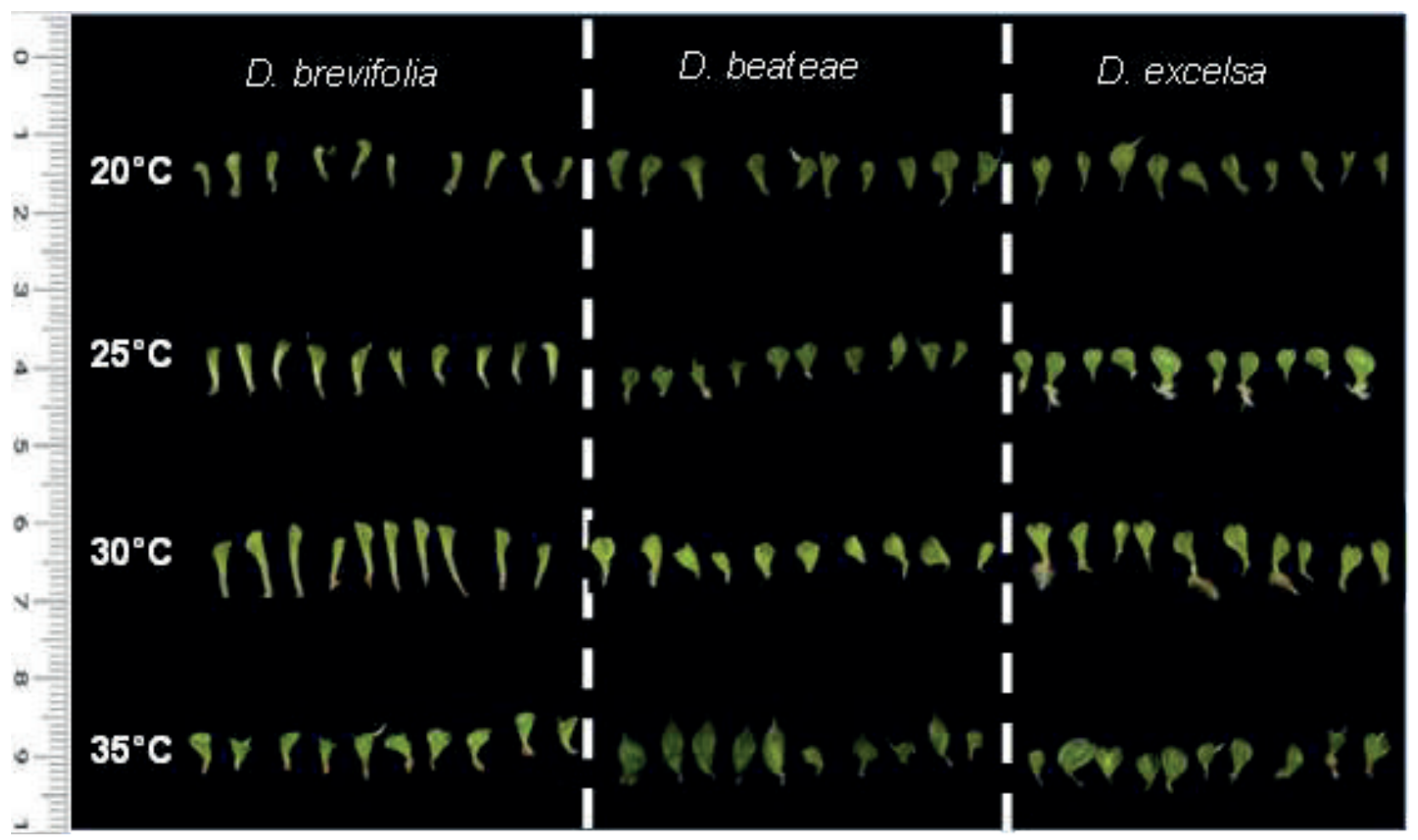

Figure 1. Development of seedlings of Dyckia excelsa, Dyckia brevifolia, and Dyckia beateae at different temperatures $\left(20,25,30\right.$, and $\left.35^{\circ} \mathrm{C}\right)$. Londrina - PR, 2019.

\section{Conclusion}

Temperatures of 25 and $30^{\circ} \mathrm{C}$ support greater seed vigor and are better conditions for seedling growth and development for Dyckia excelsa and Dyckia brevifolia.

For Dyckia beateae, the best conditions for germination and seedling development are observed at $35^{\circ} \mathrm{C}$.

The first germination count of $D$. excelsa, D. beateae, and D. brevifolia must be evaluated on the third day after sowing.

Germination evaluations for D. excelsa and $D$. beateae should be carried out on the ninth day after sowing and those for $D$. brevifolia on the sixth day after sowing.

\section{Acknowledgments}

The authors would like to thank the Coordination for the Improvement of Higher Education Personnel (CAPES), the National Council for Scientific and Technological Development (CNPq), and the State University of Londrina (UEL).

\section{References}

Anacleto, A., \& Negrelle, R. R. B. (2009). Extrativismo de rametes e propagação vegetativa de Aechmea nudicaulis (L.) Griseb. (Bromeliaceae). Scientia Agraria, 10(1), 85-88. doi: 10.5380/rsa. v10i1.13529 
Arbona, V., Manzi, M., Ollas, C., \& GómezCadenas, A. (2013). Metabolomicsasa tool to investigat eabiotic stress tolerance in plants. International Journalof Molecular Sciences, 14(3), 4885-4911. doi: 10.3390/ ijms14034885

Ataíde, G. M., Borges, E. E. L., Gonçalves, J. F. C., Guimarães, V. M., Flores, A. V., \& Bicalho, E. M. (2013). Alterations in seed reserves of Dalbergia nigra ((Vell.) FrAll. ex Benth.) during hydration. Journal of Seed Science, 35(1), 56-63. doi: 10.1590/ S2317-15372013000100008

Benson, E. E. (2008). Cryopreservation of phyto diversity: a critical appraisal of theory \& practice. Critical Reviews in Plant Sciences, 27(3), 141-219. doi: 10.10 80/07352680802202034

Bered, F., Santos, K. E., Palma, S. C., \& Paggi, G. M. (2008). Bromélias - a beleza exótica do Novo Mundo. In R. L. Barbieri, \& E. R. T. Stumpf (Eds.), Origem e evolução de plantas cultivadas (pp. 235-251). Brasília: EMBRAPA Informação Tecnológica.

Carvalho, N. M., \& Nakagawa, J. (2000). Sementes: ciência, tecnologia e produção (4a ed.). Jaboticabal: FUNEP.

Duarte, E. F., Carneiro, I. F., Silva, N. F., \& Guimarães, N. N. R. (2010). Características físicas e germinação de sementes de Dyckia goehringii Gross \& Rauh (Bromeliaceae) sob diferentes temperaturas. Pesquisa Agropecuária Tropical, 40(4), 422-429. doi: 10.5216/pat. v40i4.6037

Dürr, C., Dickie, J. B., Yang, X. Y., \& Pritchard, H.W. (2015). Ranges of critical temperature and water potential values for the germination of species worldwide: Contribution to a seed trait data base. Agricultural and Forest Meteorology, 200(1), 222-232. doi: 10.1016/j.agrformet.2014.09.024

Ferreira, E. G., Matos, V. P., Sales, A. G., \& Pacheco, M. V. (2008). Influência da temperatura e do substrato na germinação e desenvolvimento inicial de plântulas de rúcula (Eruca sativa Mill). Revista Brasileira de Ciências Agrárias, 3(3), 209-212. doi: 10.5039/agraria.v3i3a234

Givnish, T. J., Barfuss, M. H. J., Van, E. E. B., Riina, R., Schulte, K., Horres, R.,... Sytsma, K. J. (2011). Phylogeny, adaptive radiation, and historical biogeography in bromeliaceae: insights from an eight-locus plastid phylogeny. American Journal of Botany, 98(5), 1-24. doi: 10.3732/ajb.1000059

Gualtieri, S. C. J., \& Fanti, S. C. (2015). Germinação de sementes: ecofisiologia da germinação de sementes. In F. C. M. Piña-Rodrigues, M. B. Figliosa, \& A. Silva (Eds.), Sementes florestais tropicais: da ecologia à produção. (pp. 259-275). Londrina: ABRATES.

Guedes, R. S., Alves, E. U., Gonçalves, E. P., Santos, S. R. N. dos, \& Lima, C. R. (2009). Testes de vigor na avaliação da qualidade fisiológica de sementes Erythrina velutina Willd. (Fabaceae Papilionoideae). Ciênciae Agrotecnologia, 33(5), 1360-1365. doi: 10.1590/S141370542009000500023

Kovalenko, O. A., \& Kalista, M. S. (2019). Germination Biology of Parthenocissus quinquefolia (L.) Planch. (Vitaceae). Brazilian Journal of Botany, 29(2), 179190. doi: 10.33542/TJB2019-2-04 
Leme, E. M., Ribeiro, O. B. D. C., \& Miranda, Z. D. J. (2012). New species of Dyckia (Bromeliaceae) from Brazil. Phytotaxa, 67(1), 9-37. doi: 10.11646/ phytotaxa.67.1.2

Maguire, J. D. (1962). Speed of germination-aid in selection and evaluation for seedling emergence and vigor. Crop Science, 2(2), 176-177. doi: 10.2135/cropsci1962.0011 183X000200020033x

Marcos, J., Fo. (2015). Fisiologia de sementes de plantas cultivadas. Piracicaba: Fealq.

Ministério da Agricultura, Pecuária e Abastecimento (2009). Regras para análise de sementes. Brasília: Mapa/ACS. Recuperado de http://www.agricultura. gov.br/assuntos/laboratorios/arquivospublicacoes-laboratorio/regras-paraanalise-de-sementes.pdf/view

Nakagawa, J. (1999). Testes de vigor baseado no desempenho das plântulas. Vigor de sementes: conceitos e testículos (v. 1). Londrina: ABRATES.

Pacheco, F. Jr., Silva, J. B., Negreiros, J. R. S., Silva, M. R. G., \& Farias, S. B. (2013). Germinação e vigor de sementes de pimenta-longa (Piper hispidinervum) em função da temperatura e da luz. Revista Ciência Agronômica, 44(2), 325-333. doi: 10.1590/S1806-66902013000200015

Pinheiro, F., \& Borghetti, F. (2003). Light and temperature quirements for germination of seeds of Aechmea nudicaulis (L.) Griesebach and Streptocalyx floribundus (Martius ex Shultes f.) Mez (Bromeliaceae). Acta Botanica Brasilica, 17(1), 27-35. doi: 10.1590/S0102-33062003000100003
Pompelli, M. F. (2006). Germinação de Dyckia encholirioides var. enchorilirioides (Bromeliaceae-Pticairnioideae). Floresta e Ambiente, 13(1), 1-9.

Rajjou, L., Duval, M., Gallardo, K., Catusse, J., Bally, J., Job, C., \& Job, D. (2012). Seed germination and vigor. Annual Review of PlantBiology, 63(1), 507-533. doi: 10.1146/ annurev-arplant-042811-105550

Reflora (2020). Bromeliaceae in Flora do Brasil 2020 em construção. Rio de Janeiro: Jardim Botânico do Rio de Janeiro. Recuperado de http://floradobrasil.jbrj. gov.br/reflora/floradobrasil/FB66

Silva, L. F., Souza, D. C., Resente, L. V., \& Gonçalves, W. M. (2018). Manejo de recursos genéticos vegetais. Anais da Academia Pernambucana de Ciência Agronômica, 15(1), 109-126.

Souza, S. C. P. M. D., Rodrigues, R. R., \& Joly, C. A. (2017). O banco de sementes e suas implicações na diversidade da Floresta Ombrófila Densa Submontana no Parque Estadual Carlos Botelho, São Paulo, SP, Brasil. Hoehnea, 44(3), 378-393. doi: 10. 1590/2236-8906-61/2016

The Plant List (2020). A working list of all plant species. Version 1.1. Retrieved from http://www. theplantlist.org/

Valadares, J., \& Paula, R. C. de. (2008). Temperaturas para germinação de sementes de Poecilanthe parviflora Bentham. (Fabaceae - Faboideae). Revista Brasileira de Sementes, 30(2), 164-170. doi: 10.1590/S0101-31222008000200020 
Vieira, D. C.M.,Socolowski, F., \& Takaki, M.(2007). Germinação de sementes de Dyckia tuberosa (Vell.) Beer (Bromeliaceae) sob diferentes temperaturas em luz e escuro. Brazilian Journal of Botany, 30(2), 183188 .doi: 10.1590/S0100-840420070002 00003
Wiesbauer, M., Scariot, E. C., Sasaki, L. L., \& Reis, A. (2007). Influência da luz e inundação na germinação de Dyckia distachya Hassler, uma bromélia em vias de extinção. Revista Brasileira de Biociências, 5(Supl. 1), 717719. 